\title{
Effect of natural antioxidants and vegetable fiber on quality properties of fish sausage produced
}

\section{from Silver carp (Hypophthalmichthys molitrix)}

\author{
Ebrahim Mahdavi ${ }^{1}$, Peiman Ariaiii ${ }^{2, *}$ \\ ${ }^{1}$ Department of Food Science \& Technology, Nour Branch, Islamic Azad University, Nour, Iran; ${ }^{2}$ Department of Food \\ Science \& Technology, Ayatolla Amoli Branch, Islamic Azad University, Amol, Iran
}

*Corresponding Author: Peiman Ariaii, Department of Food Science E Technology, Ayatolla Amoli Branch, Islamic Azad University, Amol, Iran, Email: p.aryaye@yahoo.com

Received: 21 April 2021; Accepted: 27 July 2021; Published: 23 August 2021

(c) 2021 Codon Publications

OPEN ACCESS (c) ()요 (2)

PAPER

\begin{abstract}
In this study, production of low-fat, nitrite-free sausage based on Silver carp surimi was performed. In order to replace oils, inulin fiber (IF) was used; natural preservatives such as grape pomace extract (GE) and nisin (NI) were used as nitrite replacements with modified atmosphere packaging (MAP: $70 \% \mathrm{CO}_{2}+30 \% \mathrm{~N}_{2}$ ). For this purpose; five treatments including, T1: control, T2: control + MAP, T3: IF 5\% + MAP, T4: IF5\% + GE0.5\% + MAP, and T5: IF5\% + GE0.5\% + NI 0.5\% + MAP, were prepared. The physicochemical and texture properties of sausage at the beginning of storage and chemicals (Peroxide value, $\mathrm{pH}$, and color index) and microbial index (Total count and psychrotrophic bacteria) during 42 days' storage in the refrigerator $\left(4 \pm 1^{\circ} \mathrm{C}\right)$ were evaluated. The results showed that the use of natural preservatives had no effect on the physicochemical properties of the sausage $(\mathrm{P}>0.05)$, but the FI had a positive effect on the texture characteristics (the firmness increased and elasticity decreased), increased moisture and ash, and reduced the fat content of sausages $(\mathrm{P}<0.05)$. All in all, the best results among the treatment containing natural preservative was T5, in all microbial and chemical tests there was no significant difference with T1 $(P>0.05)$. All in all, a functional product with properties such as fiber and natural antioxidants, low fat and nitrite-free can be produced.
\end{abstract}

Keywords: fat replacement; inulin fiber; nitrite; plant extracts; nisin; fish sausage

\section{Introduction}

Seafood is a valuable source of protein for humans and plays an important role in healthy nutrition. Fish have a very high nutritional value and provide most of the essential nutrients for humans, but what makes fish a specifically important food item is the presence of fatty acids. The human body is not capable of producing some unsaturated fatty acids such as omega-3 (Kwasek et al., 2020).

Hypophthalmichthys molitrix is one of the warm water fish species that is widely cultivated in many countries of the world for its rapid growth, high feed conversion ratio, and good nutritional value (Fan et al., 2008; Stepien et al.,
2019). Despite intermuscular bones and unpleasant odor (mud), this fish, like other fish, contain high-quality protein and unsaturated fatty acids. To solve the abovementioned problems, as well as produce high value-added products from Silver carp, it needs to be processed. On the other hand, with a glance at people's livelihoods, mechanical life, and lack of time to prepare food, the idea of producing or supplying ready-to-eat or semi-prepared food, such as fish paste, fish ball, fish cake, fish sausage, and burger from seafood, seems to be a good solution (Fan et al., 2008; Ozpolat and Patir, 2015).

Nitrite is used to prevent spoilage (undesirable physicochemical and biological changes) in sausage and ham (from production to consumption). Nitrate and nitrite 
are preservatives that give a good pink color (HernándezHernández et al., 2009). Due to the potential dangers of using synthetic preservatives such as nitrite and consumers' interest in using healthy and natural products, food industry researchers favor the use of natural antioxidants in food products. The use of natural preservatives, such as extracts, powders, and essential oils of plants, to increase the shelf-life of meat products is a promising new technology, were. The active ingredients found in plants have antimicrobial and antioxidant properties (Hernández-Hernández et al., 2009; Odunayo Olatunde and Benjakul, 2018). The following are some of the compounds that have antioxidant and antimicrobial activity as nitrite substitutes.

Grape pomace is one of the waste products (5000 tons a year) produced annually in juice factories, a rich source of several valuable compounds such as citric acid, tartrate, dietary fiber, and phenolic compounds. Anthocyanin (malvidin and penonidine), flavonol (quercetin and meristine), acetylbene, and phenolic acids are the major phenolic compounds, and flavan-3-L, catechin and epi-catechin, and gallic acid are the predominant phenolic compounds in the pulp (Drosou et al., 2015). Also, due to its red color, it seems to have a pink effect on the sausage.

Nisin (NI) is a biphasic bacteriocin polypeptide containing 34 amino acids, produced by specific strains of Lactococcus lactis subsp. Lactis. Due to its antimicrobial properties and low toxicity to humans, it has long been regarded as a GRAS ${ }^{1}$ food preservative in the food industry. NI is known in two forms, A and Z, that are similar in structure and antimicrobial activity and differ in their amino acid in position 27; in type $\mathrm{A}$, histidine and the $\mathrm{Z}$ variant is asparagine (Biswaro et al., 2018).

Modified atmosphere packaging (MAP) is used in the storage of fresh (nonfrozen) foods or at least the process. The use of vacuum or modified atmosphere or high $\mathrm{CO}_{2}$ packaging is easily feasible for processed meats, but high levels of $\mathrm{CO}_{2}$ will have negative effects on product quality, especially texture changes and increased blood loss (Hematian et al., 2012).

Inulin is a nondigestible carbohydrate containing natural Fructooligosaccharides (FOS) and has dietary fiber properties that are of great interest for its consumption due to its specific health and technological properties. Inulin in the mouth creates a fatty mouth feel. The characteristic of inulin as an imitative lipid relates to its ability to bind to water molecules and form a gel-like network (Menegas et al., 2013).

${ }^{1}$ Generally Recognized as Safe.
So far, no study has been done on sausages with these preservations along with the MAP. Overall, according to the cases stated in this study, we evaluated the effect of natural antioxidants as a nitrite replacement and the use of fat substitutes to reduce the use of oil in sausage formulation produced by Silver carp surimi. MAP was also used for packaging of samples in different treatments.

\section{Material and Methods}

\section{Raw materials}

At first, $30 \mathrm{~kg}$ of silver carp were caught from the farms and transported to the laboratory in ice boxes, followed by washing and removing the skin. After this step, the underlying meat was removed without contact with the viscera and then it was ground first through a $10 \mathrm{~mm}$ plate and then through a $5 \mathrm{~mm}$ plate in a meat grinder (MKG1300P, Panasonic, Japan). All chemicals used were purchased by Merck Germany and were of an analytical grade.

\section{Preparation of treatments}

To prepare the surimi, minced meat was washed with drinking water at a temperature below $10^{\circ} \mathrm{C}$ for $10 \mathrm{~min}$ in three stages. Rinsing was performed in $0.2 \%$ brine in the third step. Surimi obtained during experiments was stored at refrigerator temperature (Shabanpour et al., 2017). The sausages contained crushed ice 10\%, liquid sunflower oil $10 \%$, extenders and binders $7 \%, \mathrm{NaCl}$ $1.5 \%$, spice mixture $1 \%$, monosodium glutamate $0.1 \%$, polyphosphate $0.3 \%$, and $70 \%$ mince. Sausage was prepared by mixing the ingredients in sequence in a food processor. The mix was stuffed into five-layer synthetic casings and cooked. Diameter and length of sausages were $25 \mathrm{~mm}$ and $20 \mathrm{~cm}$, respectively. All fish sausages were packed separately in nine labeled polyethylene zipbags and stored at $4^{\circ} \mathrm{C}$ prior to the measurements.

Inulin fiber (IF) was added to the primary sausage formulation as fat substitutes. In addition, a ranking test previously performed comparing sausage samples with IF at different concentrations showed significantly lower acceptability of the samples incorporating $6 \%$ or $7 \%$ of them when compared to the rest (5\% or lower) (data not shown). After these, IF at $5 \%$ was chosen as optimal for the following study. Fat decreased by $5 \%$. Also, extracts of orange peel, grape pomace, and NI in concentration of $0.5 \%$ (concentration approved by sensory evaluators unchanged in taste of fish sausage) were added separately and combined as a substitute for nitrite and then, the same steps were taken similar to control treatment and finally the treatments were packed into three multilayer flexible 
pouches (three and four layers) under modified atmosphere (MAP: $70 \% \mathrm{CO}_{2}+30 \% \mathrm{~N}_{2}$ ) (Rahmanifarah et al., 2013). The treatments were kept at refrigerator temperature $\left(4 \pm 1^{\circ} \mathrm{C}\right)$ for 42 days. On $0,7,14,28,35$, and 42 days of storage, three sausages from each section were randomly selected and tested to determine qualitative parameters (physicochemical and microbiological). Proximate factors and texture analysis were examined at zero time. All experiments were performed with three replications.

In total, five treatments were studied.

Treatment 1: Control treatment (no additives)

Treatment 2: Control treatment + MAP

Treatment 3: $5 \%$ oil, $5 \%$ IF + MAP

Treatment $4: 5 \%$ oil, $5 \%$ IF $+0.5 \%$ grape pomace extract (GE) + MAP

Treatment 5: $5 \%$ oil, $5 \%$ IF $+0.5 \%$ GE $+0.5 \% \mathrm{NI}+$ MAP

\section{Proximate composition}

Moisture of samples using oven at $105^{\circ} \mathrm{C}$, amount of protein by the kjeldahl method, amount of fat using petroleum ether solvent (boiling point of $40-60^{\circ} \mathrm{C}$ ) by soxhlet extraction, and ash of samples using electric furnace at $550^{\circ} \mathrm{C}$ were measured (AOAC, 2005).

\section{Cooking loss test}

Thirty grams of samples were stuffed into screw top test tubes and were heated in a steam bath at $70^{\circ} \mathrm{C}$ for $30 \mathrm{~min}$. The cooked samples were quickly immersed in cool water for $10 \mathrm{~min}$. Cooking loss was determined by weighing individual sample before and after cooking, and the difference was expressed as a percentage of the original weight (Choi et al., 2009).

\section{Texture analysis}

To measure the texture of the sausage, the cubic pieces were cut in $1 \times 1 \times 1 \mathrm{~cm}^{3}$ dimensions and subjected to compression test by a texture analyzer with a flat probe profile of $40 \times 40 \mathrm{~mm}$ and a load of $10 \mathrm{~kg}$. The force required to compress the samples to $70 \%$ of their initial height was measured at a constant rate of $200 \mathrm{~mm} / \mathrm{min}$ (Vural, 2003).

\section{Chemical analyses}

\section{Peroxide value}

Peroxide value of the samples was determined according to the Pearson method (Bagheri et al., 2016). Results were expressed in meq oxygen $\mathrm{kg}^{-1}$ lipids.

\section{pH value}

Five grams of each sample were added to $45 \mathrm{~mL}$ of distilled water and placed in a mixer for $30 \mathrm{~s}$. Then, the $\mathrm{pH}$ of the samples was measured with a digital $\mathrm{pH}$ meter calibrated to $\mathrm{pH}$ four and seven standards (Valipour et al., 2017).

\section{Color test}

The color of the sausage was measured using the Hunterlab colorflex colorimeter (Hunter Lab Inc). The color test results include three Hunter indices $\mathrm{a}^{*}, \mathrm{~b}^{*}, \mathrm{~L}^{*}$, where $L^{*}$ is a light symbol which is black (0) and white (100), a* is a green-to-red symbol, $-\mathrm{a}$ is green, and $+\mathrm{a}$ is red and $b^{* *}$ are blue to yellow symbol, which $+b$ is yellow and $-b$ is blue. The experiment was performed in triplicates (Choi et al., 2009).

\section{Microbial analyses}

Ten grams of each sample were mixed and homogenized with $90 \mathrm{~mL}$ sterile sodium chloride solution and the required dilutions were prepared. One milliliter of each dilution was used for culture by pour plate method. Total count and psychrotrophic bacteria were counted on Plate Count Agar at $37^{\circ} \mathrm{C}$ for 2 days and $7^{\circ} \mathrm{C}$ for 10 days. The results were reported as $\log \mathrm{CFU}^{2} / \mathrm{g}$ (Javadian et al., 2017).

\section{Mold and yeast test}

Dilution of the sample was first prepared in Peptone Water broth, then transferred to a plate containing $\mathrm{DRBC}^{3}$ medium. Plates were aerobically incubated at $25^{\circ} \mathrm{C}$ for 5 days (ISIRI, 2008)

\section{Inoculation and enumeration of Clostridium botulinum to ham samples}

Approximately $10^{8} \mathrm{CFU} / \mathrm{mL}$ of Clostridium botulinum were added to the ham samples. The samples were then massaged to ensure complete mixing of the bacterium with the hams and placed in specially filled coatings in the baking chamber. At least 10 hams were considered for each treatment. All treatments were packed in zippered nylon bags and stored at refrigerator temperature $\left(4 \pm 1^{\circ} \mathrm{C}\right)$ during the experiment. For bacterial count at each sampling time, $1 \mathrm{~g}$ of sample was mixed with $9 \mathrm{~mL}$ of physiological serum and suspended for half an hour. Depending on the sample, the dilutions range from $10^{2}$ to $10^{4}$. One milliliter of diluted sample was poured into the petri dish and then $10-15 \mathrm{~mL}$ of SC agar medium

${ }^{2}$ colony-forming unit

${ }^{3}$ Dichloran Rose bengal Agar 
at $44-47^{\circ} \mathrm{C}$ was added to the petri dish and thoroughly mixed. After solidification of the medium, about $10 \mathrm{~mL}$ of the same medium was poured into the petri dish. Plates were then placed in an anaerobic jar and incubated at $37^{\circ} \mathrm{C}$ for $22 \mathrm{~h}$. At the end of incubation, all plates containing less than 150 colonies were selected and the black colonies on each plate indicating the probability of C. botulinum were counted (ISIRI, 1994).

\section{Statistical analysis}

All experiments were performed in a completely randomized design as triplicates and the result was reported as mean \pm SD. Statistical analysis of treatments was performed by ANOVA using SPSS software. Significant mean differences were determined by the Duncan test at 0.05 level and charts were plotted using Microsoft Excel software.

\section{Results and Discussion}

\section{Proximate factors}

The results of moisture content (Table 1) in different treatments showed that replacement of oil with IF increased moisture content $(P<0.05)$. But, two treatments that used natural preservatives had no significant effect on moisture content $(P>0.05)$. The lowest values were observed in control treatments ( 1 and 2$)$ and the highest moisture content was observed in treatments 3,4 , and 5 (treatments containing IF). This is due to the high water absorption properties of the fiber and also because the fiber improves the stability of the emulsion (Choi et al., 2010). Hydrocolloids are also very important factors in bonding with water and keeping it in the product. So, the increase in moisture after adding fiber is obvious (Sahin et al, 2005).

Results of fat content (Table 1) showed that replacement of oil with IF reduced fat levels. The highest fat content was observed in control (1 and 2) treatments and the lowest fat content was observed in treatments 3,4 , and 5 (treatments containing IF) $(P<0.05)$. Menegas et al. (2013) by replacing IF in chicken sausage fermented with corn oil ( $45 \%$ fat) produced a low-fat sausage with $25 \%$ fat.

Results of protein content (Table 1) in different sausage treatments showed that replacement of oil with IF had no significant effect on protein content. All treatments had no significant difference $(P>0.05)$. Menegas et al. (2013) reported that the use of IF in fermented chicken sausage had no significant effect on protein content.

Results of ash content (Table 1) in different sausage treatments showed that replacement of oil with IF increased the ash content. The lowest values were observed in control treatments (1 and 2) and the highest amounts of ash were observed in treatments 3,4 , and 5 (treatments containing IF). Increasing ash by adding IF may be due to the fact that IF has significant amounts of ash $(P<0.05)$. Cegiełka and Tambor (2012) reported that adding IF to Polish chicken burger increased burger ash content.

\section{Texture analysis}

According to the results (Figure 1a), replacement of oil with inulin increased the firmness values. The lowest values were observed in control treatments ( 1 and 2$)$ and the highest values were observed in treatments 4 and 5 (treatments containing IF) $(P<0.05)$. Adding fiber seems to increase the ability of the protein to bind to meat. Thus, it creates a firmer and coherent texture and prevents deformation of the sausage (Álvarez et al., 2012). By definition, elasticity refers to the rate of return of the sample to its original state after removal of the deformation force. Elasticity is inversely related to the degree of firmness of the treatment. In fact, the formation of a stable network structure increases the elasticity (Zhou et al., 2010). According to the results (Figure 1b), the highest values were observed in control treatments ( 1 and 2$)$ and the lowest values were observed in treatments 3,4 , and 5

Table 1. Proximate factors of different treatments of sausage.

\begin{tabular}{lllll} 
Treatment/Proximate factors & Moisture (\%) & Fat (\%) & Protein (\%) & Ash (\%) \\
\hline 1 & $61.94 \pm 0.10^{\mathrm{b}}$ & $19.64 \pm 0.37^{\mathrm{a}}$ & $18.29 \pm 0.32^{\mathrm{a}}$ & $1.73 \pm 0.02^{\mathrm{b}}$ \\
2 & $62.00 \pm 0.43^{\mathrm{b}}$ & $19.78 \pm 0.40^{\mathrm{a}}$ & $17.94 \pm 0.43^{\mathrm{a}}$ & $1.78 \pm 0.02^{\mathrm{b}}$ \\
3 & $67.89 \pm 0.36^{\mathrm{a}}$ & $14.70 \pm 0.40^{\mathrm{b}}$ & $18.17 \pm 0.32^{\mathrm{a}}$ & $2.09 \pm 0.02^{\mathrm{a}}$ \\
4 & $67.75 \pm 0.43^{\mathrm{a}}$ & $14.95 \pm 0.30^{\mathrm{b}}$ & $18.18 \pm 0.32^{\mathrm{a}}$ & $2.11 \pm 0.03^{\mathrm{a}}$ \\
5 & $67.54 \pm 0.44^{\mathrm{a}}$ & $15.11 \pm 0.14^{\mathrm{b}}$ & $17.91 \pm 0.31^{\mathrm{a}}$ & $2.03 \pm 0.03^{\mathrm{a}}$ \\
\hline
\end{tabular}

a,b,cDifferent small letters in the same column represents significant difference $(P<0.05)$ (T1: control, T2: control +MAP, T3: FI 5\% +MAP, T4: FI 5\% +GE 0.5\%+ MAP, T5: FI 5\% +GE 0.5\% +N 0.5\%+ MAP). 
(A)

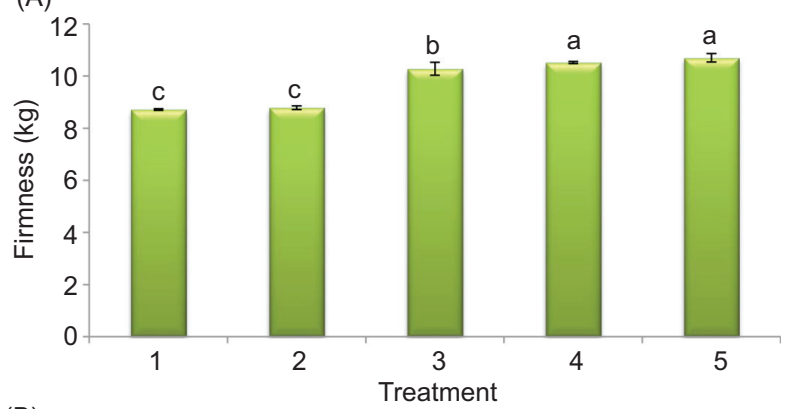

(B)

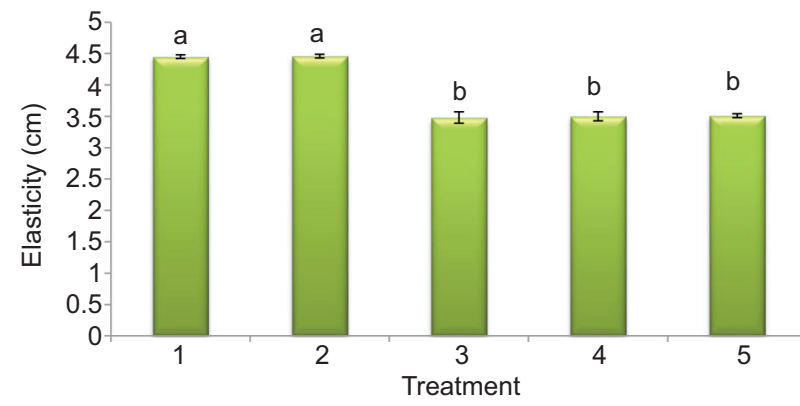

Figure 1. Texture analysis of different treatments of sausage [firmness (A) elasticity (B)] (T1: control, T2: control +MAP, T3: FI 5\% +MAP, T4: FI 5\% +GE 0.5\%+ MAP, T5: FI 5\% +GE $0.5 \%+\mathrm{N} 0.5 \%+\mathrm{MAP})$.

(treatments containing IF). Amina et al. (2014) examined the effect of adding 5\%,10\%, and $15 \%$ apple waste fiber to meat nugget texture. Apple fiber increased texture firmness and reduced nugget elasticity.

\section{Cooking loss}

Cooking sausage efficiency depends on cooking temperature, cooking time (Kim and Chin, 2007), ingredients, and fat content in the product (Huang et al., 2005). The results of cooking loss (Figure 2) in the present study showed that with increasing time the values of cooking loss increased in all treatments. Replacing the oil with IF reduced the cooking loss. The highest values were observed in control (1 and 2) on all days of storage and the lowest values were observed in treatment 3 (treatments containing IF) $(P<0.05)$. Loss of cooking is associated with the amount of fat and water-holding capacity (Eldemery, 2010). Adding dietary fiber to meat products appears to improve water-holding capacity and improve emulsion, thereby increasing cooking efficiency (Choi et al., 2010). Various researchers have suggested this as the capacity to bind to water in dietary fiber that improves tissue properties (Choi et al., 2010, 2015). Eldemery (2010) also reported that adding orange fiber to meat burger formulation decreased burger cooking loss and with increasing concentration, lower cooking loss were observed.

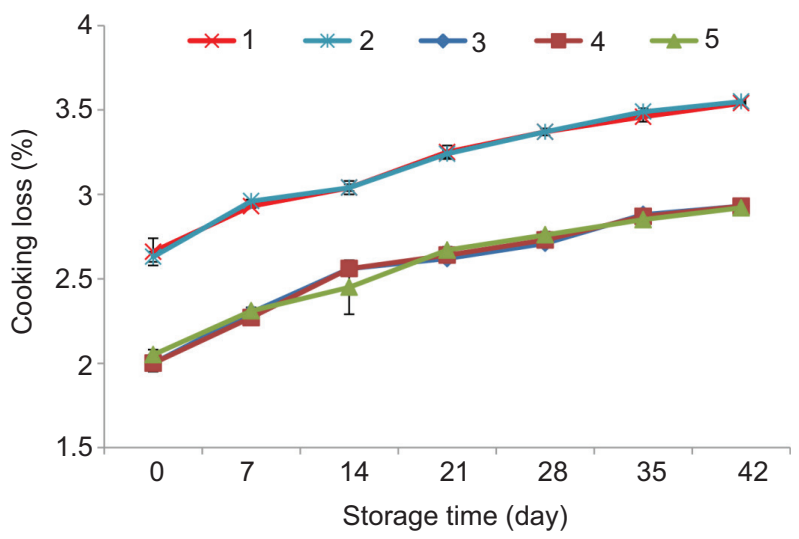

Figure 2. Cooking loss of different treatments during storage) T1: control, T2: control +MAP, T3: FI 5\% +MAP, T4: FI 5\% +GE 0.5\%+ MAP, T5: FI $5 \%+$ GE $0.5 \%+$ N 0.5\%+ MAP).

\section{Peroxide value}

According to the results of the present study (Figure 3a), the peroxide value increased in all treatments with increasing time $(P<0.05)$; the increase of peroxide value in meat products was also reported by other researchers (Javadian et al., 2017; Valipour et al., 2017). The use of MAP slowed the increase in peroxide value, so that the lowest values of peroxide were observed in the nitrite-containing treatments with the modified atmosphere $(P<0.05)$. The high level of carbon dioxide used in MAP prevents the growth of aerobic bacteria. The highest level of carbon dioxide in MAP has been reported up to 50\% (Silbande et al., 2018). The lowest values were observed on all days of treatment after treatment 2 , in treatments 1 and $5(P<0.05)$. The lower peroxide value in the inulin treatment is due to the lower fat content in these treatments and thus to the reduction of oxidative spoilage. Also, using two preservatives together more effectively decreased the peroxide value. Plant extracts contain phenolic compounds. Polyphenols are capable of trapping free radicals, especially proxy radicals, which are one of the key intermediate chain reactants, thereby terminating the cycle of oxidative spoilage reactions. Thus, the effect of treatments containing extracts had a higher effect on increasing the peroxide value (Fidan et al., 2019). The reason for the lower peroxide value after addition of NI can be attributed to the effect of bacteriocin on the decrease in lipolytic bacteria (such as Pseudomonas species) (Dehbandi et al., 2014). Dehbandi et al. (2014) also reported that the use of NI slowed the peroxide value in the Kilka fish surimi during storage.

The acceptable level of peroxide in meat for human consumption is 5 (Yanar, 2007). In relation to sausage at the 


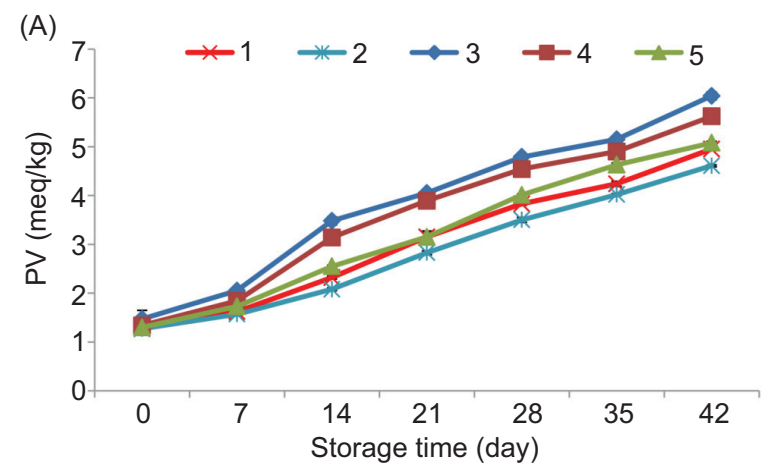

(B)

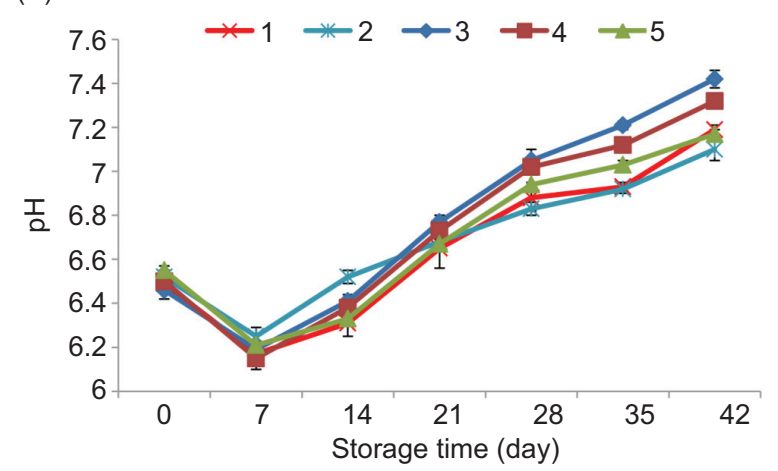

Figure 3. Changes in peroxide value (PV) $(\mathrm{A})$ and $\mathrm{pH}(\mathrm{B})$ of different treatments during storage (T1: control, T2: control +MAP, T3: FI 5\% +MAP, T4: FI 5\% +GE 0.5\%+ MAP, T5: FI 5\% +GE $0.5 \%+\mathrm{N} 0.5 \%+$ MAP).

end of the storage period, the peroxide value was at an acceptable level in all samples except treatments 3 and 4.

\section{$\mathrm{pH}$ value}

The $\mathrm{pH}$ value of food affects microbial flora composition. In fish, gram-negative and proteolytic microorganisms are dominant. In many foods of animal origin, such as poultry, meat, fish, and dairy products, $\mathrm{pH}$ reduction occurs during storage due to chemical changes such as post-slaughter changes in meat or processing. If the food storage time is increased and the microorganisms proliferate, the $\mathrm{pH}$ will rise and will be contaminated with the infection and food born microorganisms. Results of sausage $\mathrm{pH}$ values (Figure $3 \mathrm{~b}$ ) in the present study showed that $\mathrm{pH}$ values first decreased and then increased. The initial decrease in $\mathrm{pH}$ may be due to the activity of lactic acid bacteria and acidification of the environment. But, the increase in $\mathrm{pH}$ after storage time is due to the natural pattern of spoilage of meat products that is related to the activity of spoilage by microorganisms (Kim et al., 2011). The use of modified atmosphere slowed the $\mathrm{pH}$ value. High levels of carbon dioxide reduce bacterial growth and result in slowing the increase in $\mathrm{pH}$ compared to the control treatment. Overall, the lowest $\mathrm{pH}$ values were observed in nitrite + modified atmosphere treatment. Using two preservatives more effectively decreased the $\mathrm{pH}$ value. Overall, the lowest values were observed on all days of treatment after treatment 2 in treatments 1, 5 $(P<0.05)$. The latter treatments had no significant difference $(P>0.05)$. The low $\mathrm{pH}$ of the sausages treated with the extract is due to its antioxidant properties and the phenolic compounds present in the extract that can protect the sausages from the function of the internal proteases and thus inhibit protein breakdown and production of amines (Fan et al., 2008). The mechanism of NI is due to its antibacterial properties and reduction in the capacity of bacteria for oxidative deamination of nonprotein nitrogen compounds (such as ammonia and trimethylamine), thereby reducing the $\mathrm{pH}$-increasing process (Dehbandi et al., 2014).

\section{Color test}

The color index $\mathrm{L}$ indicates the brightness symbol (black to white). So, more the L, lighter the meat. The color index $\mathrm{a}$ is the indicator of the color change from green to red. The color index b represents the color change from blue to yellow. Results of color index showed that replacement of nitrite with preservative reduced color index $\mathrm{L}$ and a, and increased color index b. Sodium nitrate and nitrite are used to create a bright red (pink) and prevent turbidity of meat products, as well as antimicrobial preservatives, to create a special flavor.

So, it seems natural to replace nitrite with other compounds and change its color. According to the results of using modified atmosphere, the color index $\mathrm{L}$ decreases (Figure 4A). Overall, the highest values were observed at the end of the storage period after the control treatments in treatment 5 . There was no significant difference between the two latter treatments $(\mathrm{P}<0.05)$. This indicates that the oxidation process is decreased. In fact, the brightness values of the sausage samples are correlated with the peroxide values. As the number of peroxides increases, the brightness decreases and the samples darken. In fact, it can be stated that the use of three preservatives, prevents oxidation of pigments and act as a chemical preservative such as nitrite.

The color index a (Figure 4B) also decreased in all treatments. Generally, one of the causes of oxidation in meat products is the presence of compounds such as myoglobin and hemoglobin, which in the presence of metals, such as iron, act as peroxidants. Thus, it is one of the factors affecting the oxidation of oxymyoglobin (light red) to metmyoglobin (brown color) during the storage of meat products. Therefore, as a result of redox oxidation, color index a is reduced (Jin et al., 2007). 

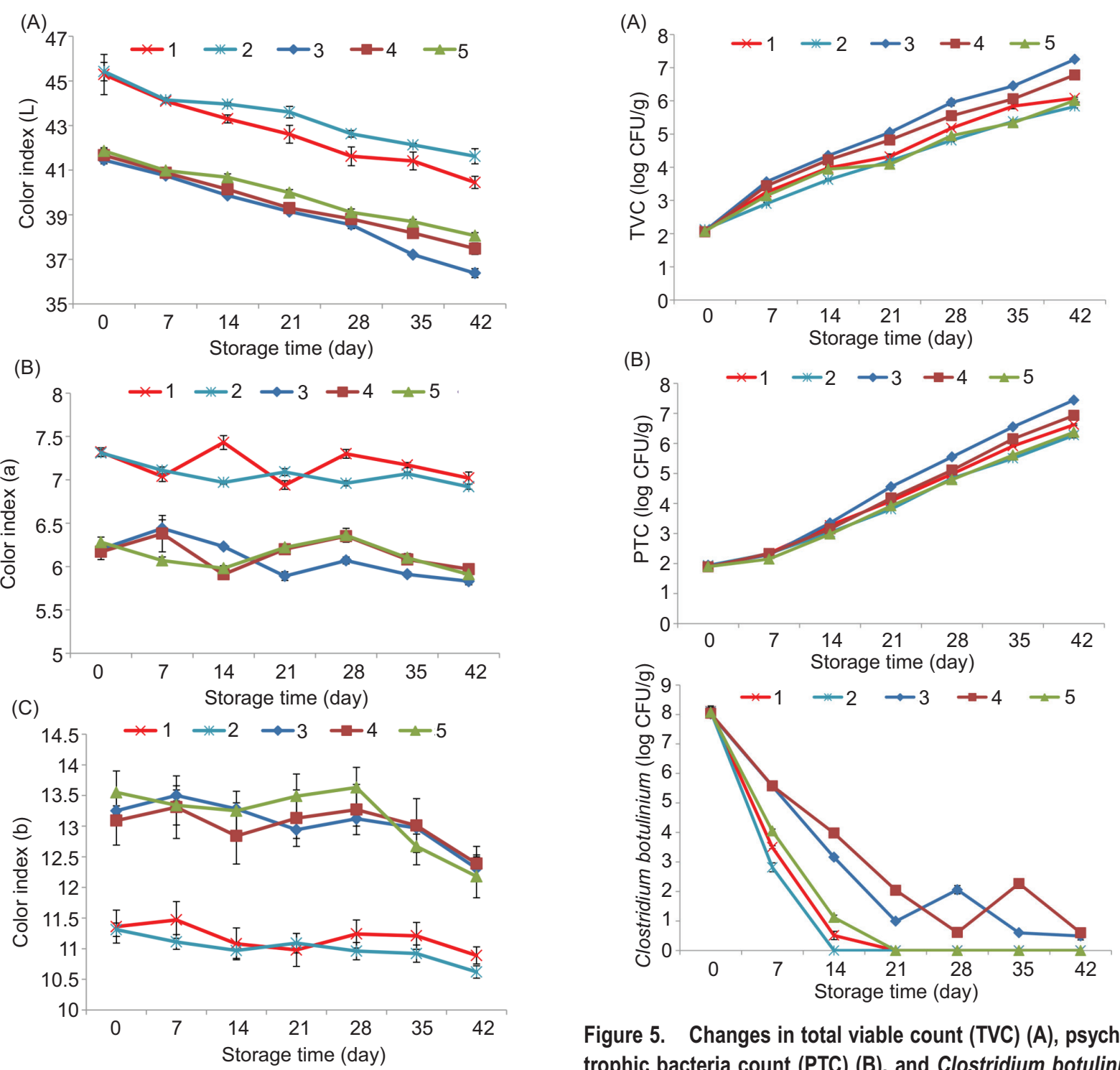

Figure 4. Changes in color index $L, b$, and a (A, B, and C, respectively) of different treatments during storage (T1: control, T2: control +MAP, T3: FI 5\% +MAP, T4: FI 5\% +GE 0.5\%+ MAP, T5: FI $5 \%+$ GE $0.5 \%+\mathrm{N} 0.5 \%+$ MAP).

The color index b (Figure 4C) decreased and increased during the storage period, which was consistent with the results of Giatrakou et al. (2010), who also reported that yellow index changes in meat products did not have a specific pattern and can change during storage by product type, formulation, and form of packaging.

\section{Total and psychrotrophic bacteria}

The results of total count bacteria (TVC) (Figure 5A) and psychotrophic bacteria (PTC) (Figure 5B) were somewhat consistent $(P<0.05)$ and were increased during storage time $(P<0.05)$. MAP decreased the growth of TVC and

PTC so that the lowest values were observed in nitrite + modified atmosphere treatment (treatment 2). Gases used in modified atmosphere, such as carbon dioxide, have antimicrobial activity, and their mechanism is to dissolve in the water content of the food and produce carbonic acid, which enters the cell membrane of the microorganism and after ionization disrupts intracellular electrical balance and ultimately causes bacterial death (Hematian et al., 2012). Use of two preservatives together more effectively slowed down the growth of TVC. The lowest values were observed on all days of treatment 2 and then in treatment 1 and treatment $5(P<0.05)$, and similar results were observed with PTC bacteria, indicating a positive effect of the two preservatives as a substitute for nitrite in sausages. The lower TVC and PTC in the extract-containing treatments can be 
due to phenolic compounds such as cineol. Phenolic compounds in plant extracts destroy the microorganisms and cause liposaccharides to exit and increase the permeability of the cytoplasmic membrane to ATP ${ }^{4}$. ATP release leads to the termination of cell energy storage and cell death (Burt, 2004). NI causes a gap in the plasma membrane and the cytoplasmic components secreted in the surrounding plasma space, and the ability of the compounds to transfer to the plasma membrane is impaired, and after ATP hydrolysis, cell death occurs. The anionic lipid present in the membrane is an active site for NI binding (Li et al., 2016).

In the present study, no mold or yeast was observed.

\section{Clostridium botulinum}

Clostridia are bacteria that occur in the environment and on the flora of the intestines of humans and animals (Wagner et al., 2006). Results of C. botulinum (Figure 5C) showed that with increasing time, C. botulinum decreased in all treatments. According to the results of the MAP, the process of growth of C. botulinum was slowed so that on day 14 the lowest value of the bacterium was observed in control + MAP treatment (T2). The use of the preservative effectively inhibited the bacterium as no treatment was observed on day 21 due to the antimicrobial activity of the extracts. Phenolic compounds in plant extracts destroy microorganisms, resulting in the release of liposaccharides and increased permeability of the cytoplasmic membrane to ATP. ATP withdrawal results in the depletion of cell energy storage and cell death (Burt, 2004). C. botulinum is a gram-positive bacterium, and the fact that NI is effective against gram-positive bacteria but not effective against gram-negative bacteria has been well established. NI is specifically active against vegetative cells and heat-resistant spores of Bacillus, Clostridium, and Listeria monocytogenes. The mechanism of NI antimicrobial activity against the vegetative walls of cells is binding to the cytoplasmic membrane. NI is a cationic antimicrobial that binds to electrons with a negative charge through electrostatic bonding. After binding, NI enters the membrane and creates a temporary small cavity. This process causes the rapid release of ions, amino acids, and cellular ATP (Vongsawasdi et al., 2012).

\section{Conclusion}

The results of the present study showed that addition of IF had a positive effect on a physicochemical and texture of sausages. Also, the use of two natural preservatives combined with modified atmosphere had almost similar

\footnotetext{
${ }^{4}$ Adenosine triphosphate
}

chemical and microbial properties to conventional sausage treatment (containing nitrite). Among the treatments containing natural preservatives, the best results were observed in treatment 5 ( $5 \%$ oil, $5 \% \mathrm{IF}+0.5 \% \mathrm{GE}+$ $0.5 \% \mathrm{NI}+\mathrm{MAP}$ ). Based on the results, a functional product with properties, such as fiber and natural antioxidants, low fat, and nitrite-free, can be produced.

\section{References}

Álvarez, D., Xiong, Y.L., Castillo, M., Payne, F.A. and Garrido, M.D., 2012. Textural and viscoelastic properties of pork frankfurters containing canola-olive oils, rice bran, and walnut. Meat Science 92: 8-15. https://doi.org/10.1016/j.meatsci.2012.03.012

Amina, B., Parveen, S., Rather, S., Akhter, R. and Hassa, M., 2014. Effect of incorporation of apple pomace on the physic-chemical, sensory and textural properties of mutton nuggets. International Journal of Advanced Research 2(4): 974-983.

AOAC, 2005. Official method of analysis (17th ed.). Washington, DC: Association of Official Analytical Chemists.

Bagheri, R., Izadi Amoli, R., Tabari Shahndash, N. and Shahosseini, S.R., 2016. Comparing the effect of encapsulated and unencapsulated fennel extracts on the shelf life of minced common kilka (Clupeonella cultriventris caspia) and Pseudomonas aeruginosa inoculated in the mince. Food Science and Nutrition 4(2): 216-222. https://doi.org/10.1002/fsn3.275

Biswaro, L.S., da Costa Sousa, M.G., Rezende, T.M.B., Dias, S.C. and Franco, O.L., 2018. Antimicrobial peptides and nanotechnology, recent advances and challenges. Frontiers in Microbiology 9: 855. https://doi.org/10.3389/fmicb.2018.00855

Burt, S., 2004. Essentialoils: their antibacterial propertied and potential application in foods - a review. International Food Mashinicrobiology 94(3): 223-253. https://doi.org/10.1016/j. ijfoodmicro.2004.03.022

Cegiełka, A. and Tambor, A., 2012. Effect of inulin on the physical, chemical and sensory quality attributes of polish chicken burgers. Journal of Food Research 1: 161-178. https://doi. org/10.5539/jfr.v1n1p169

Choi, Y.S., Choi, J.H., Han, D.J., Hack-Youn, Y., Lee, M.A., Jeong, J.Y., et al. 2010. Effects of replacing pork back fat with vegetable oils and rice bran fiber on the quality of reduced-fat frankfurters. Meat Science 84: 557-563. https://doi.org/10.1016/j. meatsci.2009.10.012

Choi, Y.S., Choi, J.H., Han, D.J., Kim, H.Y., Lee, M.A., Kim, H.Y., et al. 2009. Characteristics of low-fat meat emulsion systems with pork fat replaced by vegetable oils and rice bran fiber. Meat Science 82: 266-271. https://doi.org/10.1016/j. meatsci.2009.01.019

Choi, Y., Kim, H.-W., Hwang, K.E., Song, D.-H., Jeong, T.-J., Kim, T.-B., et al. 2015. Effects of fat levels and rice bran fiber on the chemical, textural, and sensory properties of frankfurters. Food Science and Biotechnology 24(2): 489-495. https://doi. org/10.1007/s10068-015-0064-5

Dehbandi, A., Motallebi, A.A., Razavilar, V. and Pourgholam, R., 2014. Effect of nicin $\mathrm{z}$ on some of spoilage chemical and 
bacterial properties in surimi of kilka (Clupeonella cultriventris caspia) stored in $4^{\circ} \mathrm{C}$. Iranian Scientific Fisheries Journal 23(3): 41-56. https://doi.org/10.22092/isf.2014.103540

Drosou, C., Kyriakopoulou, K., Bimpilas, A., Tsimogiannis, D. and Krokida, M.A., 2015. Comparative study on different extraction techniques to recover red grape pomace polyphenols from vinification by products. Industrial Crops and Products 75: 141149. https://doi.org/10.1016/j.indcrop.2015.05.063

Eldemery, M.E., 2010. Effect orange albedo as a new source of dietary fiber on characteristics of beef burger. In The 5th Arab and 2nd International Annual Scientific Conference on: Recent Trends of Developing Institutional and Academic Performance in Higher Specific Education Institutions in Egypt and Arab World. Mansoura University, Egypt.

Fan, W., Chi, Y. and Zhang, S., 2008. The use of a tea polyphenol dip to extend the shelf life of silver carp (Hypophthalmicthys molitrix) during storage in ice. Food Chemistry 108: 148-153. https://doi.org/10.1016/j.foodchem.2007.10.057

Fidan, H., Stefanova, G., Kostova, L., Stankov, S., Damyanova, S., Stoyanova, A., et al. 2019. Chemical composition and antimicrobial activity of Laurus nobilis L. essential oils from Bulgaria. Molecules 24: 804. https://doi.org/10.3390/molecules24040804.

Giatrakou, V., Ntzimani, A. and Savvaidis, I., 2010. Effect of chitosan and thyme oil on a ready to cook chicken product. Food Microbiology 27: 132-136. https://doi.org/10.1016/j.fm.2009.09.005

Hematian Sourki, A., Ghiafeh Davoodi, M., Tabatabaei Yazdi, F., Mortazavi, S.A., Karimi, M., Razavizadegan Jahromi, S.H., et al. 2012. Studies on the effects of packaging type and modified atmosphere on properties of Barbari bread fortified with whole soy flour. Food Science and Technology 9(36): 77-85.

Hernández-Hernández, E., Ponce-Alquicira, E., Jaramillo-Flores, M.E. and Guerrero Legarreta, I., 2009. Antioxidant effect rosemary (Rosmarinus officinalis L.) and oregano (Origanum vulgare L.) extracts on TBARS and color of model raw pork batters. Meat Science 81: 410-417. https://doi.org/10.1016/j. meatsci.2008.09.004

Huang, S.C., Shiau, C.Y., Liu, T.E., Chu, C.L. and Hwang, D.F., 2005. Effects of rice bran on sensory and physico-chemical properties of emulsified pork meatballs. Meat Science 70: 613-619. https:// doi.org/10.1016/j.meatsci.2005.02.009

Institute of Standards and Industrial Research of Iran (ISIRI), 1994. Searching and enumeration of Clostridium perfringens in food, (Standard No. 2197). Iran.

Institute of Standards and Industrial Research of Iran (ISIRI), 2008. Microbiology of food and animal feeding stuffs - Horizontal method for the enumeration of yeasts and moulds - Part 1: Colony count technique in products with water activity greater than 0.95. (Standard No. 10899-1). Iran.

Javadian, S.R., Shahoseini, S.R. and Ariaii, P., 2017. The effects of liposomal encapsulated thyme extract on the quality of fish mince and Escherichia coli O157: $\mathrm{H} 7$ inhibition during refrigerated storage. Journal of Aquatic Food Product Technology 26(1): 115-123. https://doi.org/10.1080/10498850.2015.1101629

Jin, S.K., Kim, I.S., Choi, Y.J. and Hur, S.J., 2007. The development of sausage including meat from spent laying Hen Surimi. Poultry Science 86: 2676-2684. https://doi.org/10.3382/ps.2006-00451
Kwasek, K., Thorne-Lyman, A. and Phillips, M., 2020. Canhuman nutrition be improved through better fish feeding practices? A review paper. Critical Reviews in Food Science and Nutrition 60(22): 3822-3835. https://doi.org/10.1080/10408398.2019.170 8698

Kim, I.S., Jin, S.K. and Mandal, P.K., 2011. Quality of low-fat pork sausages with tomato powder as colour and functional additive during refrigerated storage. Journal of Food Science and Technology 48(5): 591-597. https://doi.org/10.1007/s13197-010-0182-2

Kim, S.H. and Chin, K.B., 2007. Physico-chemical properties and changes of sarcoplasmic protein bands of chicken meat cuts with or without salt during cooking temperature. Korean Journal of Animal Science and Technology 49(2): 269-278. https://doi. org/10.5187/JAST.2007.49.2.269

Li, H., Xu, Z., Zhao, F., Wang, Y. and Liao, X., 2016. Synergetic effects of high-pressure carbon dioxide and nisin on the inactivation of Escherichia coli and Staphylococcus aureus. Innovative Food Science \& Emerging Technologies 33: 180-186. https:// doi.org/10.1016/j.ifset.2015.11.013

Menegas, L., Colombo Pimentel, T., Garcia, S. and Helena Prudencio, S., 2013. Dry-fermented chicken sausage produced with inulin and corn oil: physicochemical, microbiological, and textural characteristics and acceptability during storage. Meat Science 93: 501-506. https://doi.org/10.1016/j. meatsci.2012.11.003

Odunayo Olatunde, O. and Benjakul, S., 2018. Natural preservatives for extending the shelf-life of seafood: a revisit. Comprehensive Reviews in Food Science and Food Safety 17: 1595-1512. https://doi.org/10.1111/1541-4337.12390

Ozpolat, E. and Patir, B., 2015. Determination of shelf life for sausages produced from some freshwater fish using two different smoking methods. Journal of Food Safety 36(1): 69-76. https:// doi.org/10.1111/jfs.12214

Rahmanifarah, K., Shabanpour, B. and Shabani, A., 2013. Effect of thermal microbial inactivation and washing on quality properties of fish sausage during cold storage $\left(4^{\circ} \mathrm{C}\right)$. Journal of Aquatic Food Product Technology 24(4): 386-396. https://doi.org/10.10 80/10498850.2013.781723

Sahin, S., Sumnu, G. and Altunakar B., 2005. Effects of batters containing different gum types on the quality of deep-fat fried chicken nuggets. Journal of the Science of Food and Agriculture 85: 2375-2379. https://doi.org/10.1002/jsfa.2258

Silbande, A., Adenet, S., Chopin, C., Cornet, J., Smith-Ravin, J., Rochefort, K., et al. 2018. Effect of vacuum and modified atmosphere packaging on the microbiological, chemical and sensory properties of tropical red drum Sciaenopsocellatus fillets stored at $4^{\circ} \mathrm{C}$. International Journal of Food Microbiology 266: 31-41. https://doi.org/10.1016/j.ijfoodmicro.2017.10.015.

Shabanpour, B., Neirizi, M., noori hashem abad, Z. Study the quality of silver carp (Hypophthalmichtys molitrix) Surimi during the ice storage. Iranian Food Science and Technology Research Journal, 2017; 13(1): 202-213. https://doi.org/10.22067/ifstrj. v1395i0.40216

Stepien, C.A., Snyder, M.R. and Elz, A.E., 2019. Invasion genetics of the silver carp Hypophthalmichthys molitrix across North America: differentiation of fronts, introgression, and eDNA 
metabarcode detection. PLoS One. 14(3): e0203012. https://doi. org/10.1371/journal.pone.0203012

Valipour Kootenaie, F., Ariaii, P., Khademi Shurmasti, D. and Nemati, M., 2017. Effect of chitosan edible coating enriched with eucalyptus essential oil and $\alpha$-tocopherol on silver carp fillets quality during refrigerated storage. Journal of Food Safety 37(1): e12295. https://doi.org/10.1111/jfs.12295

Vongsawasdi, P., Nopharatana, M., Supanivatin, P. and Promchana, M., 2012. Effect of nisin on the survival of Staphylococcus aureus inoculated in fish balls. As Journal of Agricultural - Industry 5(01): 52-60.

Vural, H., 2003. Effect of replacing beef fat and tail fat with interesterified plant oil on quality characteristics of Turkish semi-dry fermented sausages. European Food Research and Technology 217(2): 100-103. https://doi.org/10.1007/s00217-003-0727-y
Wagner, K., Vorauer-Uhl, K. and Katinger, H., 2006. Nebulization of liposomal rhcu/zn Sod with a novel vibrating membrane nebulizer. Journal of Liposome Research 16: 113-125. https://doi. org/10.1080/08982100600680733

Yanar, Y., 2007. Quality changes of hot smoked catfish (Clarias Gariepinus) during refrigerated storage. Journal of Muscle Foods 18: 391-400. https://doi.org/10.1111/j.1745-4573.2007.00094.x

Zhou, W.W., Meng, L., Li, X., Ma, L. and Dai, R., 2010. Effect of the interaction between carrageenan, gellan gum and flaxseed gum on quality attributes of starch-free emulsion-type sausage. Journal of Muscle Foods 21(2): 255-267. https://doi. org/10.1111/j.1745-4573.2009.00180.x 